\title{
ANTI-PROLIFERATIVE POTENTIAL OF Carica papaya LEAVES ON BREAST CANCER CELLS - MCF-7
}

\section{Sasikala Mariyappan, Sivakumar Ramalingam, Lavanya Murugan, Renuka Saravanan*}

Department of Chemistry and Biosciences, SASTRA Deemed to be University, Srinivasa Ramanujan Centre, Kumbakonam 612001, Tamil Nadu, India

Received - July 20, 2021; Revision - September 28, 2021; Accepted - October 12, 2021

Available Online - October 30, 2021

DOI: http://dx.doi.org/10.18006/2021.9(5).678.686

\section{KEYWORDS \\ Breast cancer \\ MTT assay \\ DPPH assay \\ Caria papaya \\ MCF-7}

* Corresponding author

E-mail: renuka@ src.sastra.edu (Renuka Saravanan)

Peer review under responsibility of Journal of Experimental Biology and Agricultural Sciences.

Production and Hosting by Horizon Publisher India [HPI] (http://www.horizonpublisherindia.in/).

All rights reserved.

\begin{abstract}
The study's objective is to identify the phytoconstituents and determine the anti-cancer potential of Carica papaya leaves against the MCF 7 cell line. Chloroform, ethyl acetate, and methanol extracts of C. papaya leaves were prepared by cold maceration method and qualitative phytochemical analysis was performed. The anti-proliferative effect of these extracts was determined by 3-(4,5- dimethylthiazol-2yl)-2,5-diphenyl tetrazolium bromide (MTT) assay and apoptotic assay by acridine orange/ethidium bromide staining method on MCF 7 cells. The effect of the extracts, with different concentrations, on DNA fragmentation, was also performed on MCF 7 cells. Qualitative analysis revealed the presence of alkaloids, flavonoids, terpenoids, steroids, saponins, tannins, glycosides, phenols, anthraquinones, proteins, and carbohydrates. Chloroform, methanol, and ethyl acetate extracts of $C$. papaya leaves were observed with potential DPPH free radical scavenging activity with $72 \%, 75 \%$, and $78 \%$ respectively. Of these extracts, the chloroform extract $(72 \%)$ was found to possess a more free radical scavenging effect against DPPH and also showed a dose-dependent effect, the maximum at $100 \mu \mathrm{g} / \mathrm{ml}$, on DNA fragmentation in MCF 7 cells. Further, chloroform extract showed a maximum anti-proliferative effect on MCF-7 cells with $\mathrm{IC}_{50}$ at $22 \pm 1.5 \mu \mathrm{g} / \mathrm{ml}$, whereas methanol and ethyl acetate extract at $30 \pm 0.5 \mu \mathrm{g} / \mathrm{ml}$ and $28 \pm 0.5 \mu \mathrm{g} / \mathrm{ml}$ respectively. Increased apoptosis in MCF 7 cells was observed with an increased concentration of chloroform extract of $C$. papaya. From the results of this study, it can be concluded that leaf extract of $C$. papaya found to possess an anti-proliferative effect and antioxidant potential and it could be due to the presence of rich secondary metabolites of the plant.
\end{abstract}

All the articles published by Journal of Experimental Biology and Agricultural Sciences are licensed under a Creative Commons Attribution-NonCommercial 4.0 International License Based on a work at www.jebas.org.

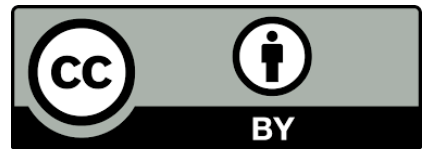




\section{Introduction}

Breast cancer is among the most common type of cancer in women around the globe (Yahyea et al., 2019). It is developed due to the inheritance of proto-oncogenes such as BRCA1, BRCA2 and by a genetic mutation. Most breast cancer is contributed by carcinoma, while sarcoma is rarely associated with this cancer (Feng et al., 2018). If the tumor is diagnosed early, it could be treated easily (Fadi \& Ferguson, 2020). Although it is seen primarily in women, men can also get breast cancer (Farr et al., 2017). Chemotherapy and radiation therapy are the commonly used treatment to treat breast cancer. But, these treatments produce adverse side effects (Alam et al., 2013). The tumor development can be reversed or inhibited by synthetic drugs. Plant extract might play an essential role in preventing and curing breast cancer (Levitsky \& Dembitsky, 2015). Medicinal plants are well recognized and have been used in the preparation of traditional medicines with fewer side effects to treat various diseases especially cancer (Richard et al., 2015). The active phytochemical constitutes of herbal plants are carotenoids, flavonoids, ligands, terpenoids, and sulfides stimulate glutathione-transferase that helps protect the cell and prevent the proliferation of the cell (Shareef et al., 2016).

Carica papaya belongs to the family of Caricaceae (Figure 1). It is diploid, dicotyledon, and polygamous plants. The papaya is consumed in the form of jam, juices, or dry fruit. The ripe fruit of C. papaya is rich in Vitamin C, A, and calcium. The different product of $C$. papaya is used to produce a variety of commercial products. Chymopapain and papain are made from latex, stem, leaves, and fruit. For many centuries, papaya leaves have been used as folk medicine. Recently researchers proved the wound healing, anti-inflammatory, anti-oxidant, immune-modulatory, and anti-tumor effect of this plant (Saurabh et al., 2016). Hence, the present study aims to analyze the phytoconstituents and to evaluate the anticancer potential of $C$. papaya leaves against the breast cancer cell line MCF 7 cells.

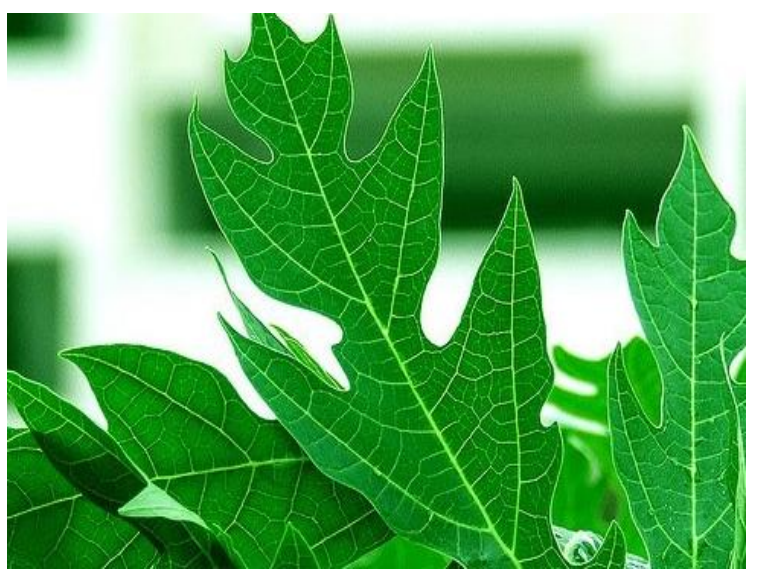

Figure 1 Caria papaya leaves

\section{Materials and Methods}

\subsection{Collection of Plant material}

The leaves of $C$. papaya were collected from Kumbakonam, Thanjavur District, Tamil Nadu, India. The leaves were shadedried, powdered with an electrical blender, and stored in an airtight container till use.

\subsection{Preparation of plant extract}

About $25 \mathrm{~g}$ of powder was immersed in $100 \mathrm{ml}$ of chloroform, ethyl acetate, and methanol separately for 72 hours with occasional shaking at room temperature. The extract was collected after filtering using Whatman No1 filter paper and stored at $4{ }^{\circ} \mathrm{C}$ till use. Then, the extracts were condensed and used for experiments (Kiruthika et al., 2020).

\subsection{Qualitative analysis of phytochemical constituents}

Qualitative analysis of phytochemical constituents was carried out by the methods of Harbone et al. (1998). The detail of the used method for qualitative analysis was given in table 1 .

Table 1 Qualitative analysis of various phytochemical constituents

\begin{tabular}{|c|c|c|c|}
\hline S.No & $\begin{array}{l}\text { Phytochemical } \\
\text { Constituents }\end{array}$ & $\begin{array}{l}\text { Appeared colour/ } \\
\text { Characteristics }\end{array}$ & Reference \\
\hline 1. & Alkaloids & $\begin{array}{l}\text { Creamy white } \\
\text { precipitate }\end{array}$ & $\begin{array}{c}\text { Mustikasari \& } \\
\text { Ariyani, } 2010\end{array}$ \\
\hline 2. & Flavonoids & Intense red color & $\begin{array}{l}\text { Chang et al., } \\
2002\end{array}$ \\
\hline 3. & Terpenoids & $\begin{array}{c}\text { Reddish-brown } \\
\text { color }\end{array}$ & $\begin{array}{c}\text { Indumathi et al., } \\
2014 \\
\end{array}$ \\
\hline 4. & Steroids & Blue-green color & Silas et al., 2019 \\
\hline 5. & Saponins & $\begin{array}{l}\text { Appearance of } \\
\text { froth }\end{array}$ & $\begin{array}{c}\text { Kokate et al., } \\
2001\end{array}$ \\
\hline 6. & Tannins & $\begin{array}{l}\text { Green-blue is } \\
\text { formed }\end{array}$ & Schanderl,1970 \\
\hline 7. & Glycosides & $\begin{array}{l}\text { Formation of } \\
\text { Green color }\end{array}$ & $\begin{array}{c}\text { Kokate et al., } \\
2001\end{array}$ \\
\hline 8. & Phenols & $\begin{array}{l}\text { Development of } \\
\text { Blue color }\end{array}$ & $\begin{array}{l}\text { McDonald et al., } \\
2001\end{array}$ \\
\hline 9. & Anthraquinones & $\begin{array}{l}\text { Appearance of } \\
\text { Rose pink color }\end{array}$ & Silas et al., 2019 \\
\hline 10. & Proteins & $\begin{array}{l}\text { Violet color is } \\
\text { formed }\end{array}$ & $\begin{array}{c}\text { Padmapriya \& } \\
\text { Maneemegalai, } \\
2014\end{array}$ \\
\hline 11. & Carbohydrates & $\begin{array}{l}\text { Appearance of } \\
\text { violet color }\end{array}$ & $\begin{array}{c}\text { Padmapriya \& } \\
\text { Maneemegalai } \\
2014\end{array}$ \\
\hline
\end{tabular}

\subsection{In-vitro anti-oxidant activity}

The anti-oxidant assay was carried out by the method of Mensor et al. (2001). In these assays, DPPH was used as the standard free radical, when it reacts with anti-oxidants, gets reduced to DPPHH. Due to the reduction reaction, the absorbance of DPPHH decreases in comparison to DPPH. The anti-oxidant activity of

Journal of Experimental Biology and Agricultural Sciences http://www.jebas.org 
compounds or extracts is indicated by the degree of discoloration in terms of hydrogen donating ability. The anti-oxidant activity of the fraction was measured in vitro by 1, 1 diphenyl- 2picrylhydrazyl (DPPH) assay (Mensor et al., 2001). In brief, 0.5 $\mathrm{mM}$ DPPH was prepared in $95 \%$ methanol, and $1 \mathrm{ml}$ of this solution was added to the tubes containing $3 \mathrm{ml}$ of leaf extracts (chloroform, methanol, and ethyl acetate) at different concentrations. The contents of the tubes were mixed well, left at room temperature for 30 minutes, and the absorbance was measured at $515 \mathrm{~nm}$ in a spectrophotometer. The antioxidant activity was expressed as:

$\%$ of disappearance $=\frac{\text { control }- \text { sample }}{\text { control }} \times 100 \quad($ Control - Sample $)$

\subsection{Cell line and culture conditions}

The human breast cancer cells (MCF-7) were purchased from the National Center for Cell Sciences (NCCS), Pune, India. The cancer cells were maintained in MEM medium (MEM+FCS) supplemented with $2 \mathrm{mM} / \mathrm{L}$ glutamine and balanced salt solution (BSS) adjusted to contain $1.5 \mathrm{~g} / \mathrm{L} \mathrm{Na} \mathrm{CO}_{3}, 0.1 \mathrm{mM}$ nonessential amino acids, $1 \mathrm{mM}$ sodium pyruvate, $2 \mathrm{mM} / \mathrm{L}$ glutamine, $1.5 \mathrm{~g} / \mathrm{L}$ glucose, $10 \mathrm{mM}$ (4-(2-hydroxyethyl)-1-piperazineethane sulfonic acid) (HEPES) and 10\% fetal bovine serum (GIBCO, USA) Penicillin and streptomycin $(100 \mathrm{IU} / 100 \mu \mathrm{g})$ were adjusted to $1 \mathrm{~mL} / \mathrm{L}$. The cells were maintained at $37^{\circ} \mathrm{C}$ with $5 \% \mathrm{CO}_{2}$ in a humidified $\mathrm{CO}_{2}$ incubator (Saravanan et al., 2017).

\subsection{MTT assay}

MTT [3-(4,5- dimethylthiazol-2-yl)-2,5-diphenyl tetrazolium bromide] assay was used to evaluate the Inhibitory Concentration $\left(\mathrm{IC}_{50}\right)$ of the plant extracts (Joseph et al., 2020). The MEM $\left(1 \times 10^{4}\right.$ cells/well $)$ was used to grow the cells in a 96 -well plate for 48 hours in $85 \%$ confluence. The medium was replaced with a fresh medium containing a serially diluted compound. The cells were then incubated for 48 hours. $100 \mu \mathrm{L}$ of the MTT [3-(4, 5dimethylthiozol-2-yl)-3,5-diphenyl tetrazolium bromide] solution was added to each well after the removal of the culture medium. Incubate the mixture at $37^{\circ} \mathrm{C}$ for 4 hours. After removing the supernatant, $50 \mu \mathrm{L}$ of DMSO/ isopropanol was added to each of the wells and incubated for 10 minutes to solubilize the formazan crystals. The absorbance was measured at $620 \mathrm{~nm}$ in an ELISA multi-well plate reader (Thermo Multiskan EX, USA). The recorded absorbance was used to calculate the percentage of viability using the following formula:

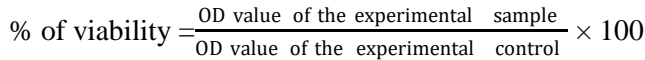

\subsection{Apoptotic analysis by Fluorescent Microscopy}

Fluorescence assay was carried out by the methods of Engin et al. (2011). For this, $0.9 \mathrm{ml}$ of cell suspension $\left(1 \times 10^{5}\right.$ cells $\left./ \mathrm{mL}\right)$ was mixed with $1 \mu \mathrm{L}$ of a dye mixture having $100 \mathrm{mg} / \mathrm{mL}$ acridine orange (AO) and $100 \mathrm{mg} / \mathrm{mL}$ ethidium bromide (EtBr) in distilled water on a clean coverslip. The phosphate-buffered saline (PBS) (pH 7.2) was used to wash pre-treated cancer that was collected. Then, using $10 \mu \mathrm{L}$ of $\mathrm{AO} / \mathrm{EtBr}$, the cells were stained; they were incubated for 2 minutes. After incubation, the cells were washed twice with PBS (5 min each) and visualized under a fluorescence microscope (Nikon Eclipse, Inc, Japan) at $400 \times$ magnification with an excitation filter of $580 \mathrm{~nm}$. The cells were treated with complex for 2 hrs by placing it on a glass coverslip in a 6-well plate. Using $2 \%$ Triton X-100 (50 $\mu \mathrm{l})$, the fixed cells were permeabilized for 10 $\mathrm{min}$ at room temperature and incubated for $3 \mathrm{~min}$ with $10 \mu \mathrm{l}$ of DAPI by placing a coverslip over the cells to enable uniform spreading of the stain. The cells were observed under (Nikon Eclipse, Inc, Japan) fluorescent microscope. The MCF-7 cells treated without plant extract were used as a control (Engin et al., 2011).

\subsection{DNA Fragmentation assay}

DNA fragmentation assay was carried out by the method of Ramar et al. (2012). In 10mM of Tris-Hcl and 10mM EDTA (pH 8.0), MCF-7 $\left(1 \times 10^{6}\right.$ cells $)$ were suspended independently. Then, the cells were treated with $10 \mathrm{mM}$ Tris- $\mathrm{HCl}, 10 \mathrm{mM}$ EDTA (pH 8.0), $2 \% \mathrm{SDS}$, and $20 \mathrm{mg} / \mathrm{mL}$ proteinase $\mathrm{K}$, and the mixture was kept at $37^{\circ} \mathrm{C}$ for $3 \mathrm{~h}$. Later, 9the mixture was extracted with phenol: chloroform: isoamyl alcohol solution in the ratio of 25:24:1, respectively. The extracted DNA was treated with DNase-free RNase at $20 \mathrm{mg} / \mathrm{mL}$ concentration at $4^{\circ} \mathrm{C}$ for $45 \mathrm{~min}$ and precipitated with $100 \mathrm{~mL}$ of $2.5 \mathrm{M}$ sodium acetate and 3 volumes of ethanol. About $10 \mu \mathrm{g}$ of isolated DNA was taken from control and treated cells and electrophoresed on a $2 \%$ agarose gel containing ethidium bromide.

\section{Results}

Results presented in table 2 revealed the phytoconstituents of chloroform, methanol, and ethyl acetate extract of C. papaya leaves. The chloroform extract of the $C$. papaya leaves was found to contain alkaloids, saponins, tannins, glycosides, proteins, and carbohydrates. Similarly, methanol extract of the C. papaya leaves contains flavonoids, terpenoids, steroids, tannins, glycosides, proteins, and carbohydrates. The ethyl acetate extract of $C$. papaya leaves contains alkaloids, saponins, tannins, glycosides, phenols, anthraquinones, proteins, and carbohydrates.

Figures 2, 3, 4 represent the anti-oxidant activity of the chloroform, methanol, and ethyl acetate extract of the $C$. papaya leaves respectively. Of these extracts, chloroform extract exerted more DPPH free radical scavenging activity than methanol and ethyl acetate extracts, but lesser with the standard ascorbic acid. 


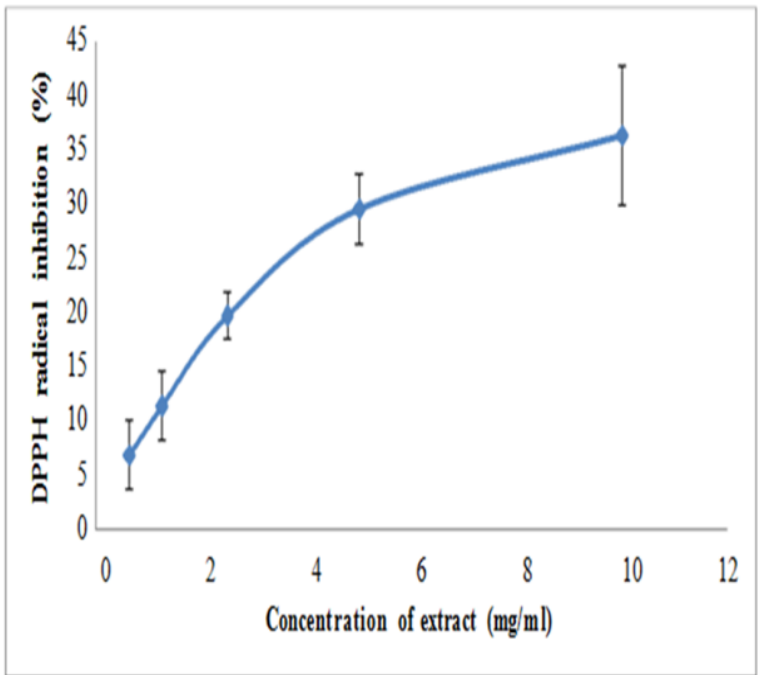

Figure 2 DPPH scavenging activity of chloroform extract of C. papaya leaves

Table 2 Phytochemical screening of the various extracts of the C. Papaya leaves

\begin{tabular}{|cc|cc|}
\hline Phytoconstituents & $\begin{array}{c}\text { Chloroform } \\
\text { extract }\end{array}$ & $\begin{array}{c}\text { Methanol } \\
\text { extract }\end{array}$ & $\begin{array}{c}\text { Ethyl } \\
\text { acetate } \\
\text { extract }\end{array}$ \\
\hline Alkaloids & + & - & + \\
\hline Flavonoids & - & + & - \\
\hline Terpenoids & - & + & - \\
\hline Steroids & - & + & - \\
\hline Saponins & + & - & + \\
\hline Tannins & + & + & + \\
\hline Glycosides & + & + & + \\
\hline Phenols & - & - & + \\
\hline Anthraquinones & - & - & + \\
\hline Protein & + & - & + \\
\hline Carbohydrates & - & + & + \\
\hline
\end{tabular}

(+) Presence (-) Negative

Figures 5, 6, 7 depict the cytotoxic effect of chloroform, methanol, and ethyl acetate of $C$. papaya leaves at $10 \mu \mathrm{g} / \mathrm{ml}, 20 \mu \mathrm{g} / \mathrm{ml}$, $40 \mu \mathrm{g} / \mathrm{ml}$ against MCF-7 cells. The percentage of viability was analyzed by MTT assay after treatment of $C$. papaya leaves extracts. The $\mathrm{IC}_{50}$ values of chloroform, methanol, ethyl acetate extracts on MCF-7 cells was found to be $22 \pm 1.5 \mu \mathrm{g} / \mathrm{ml}, 30 \pm 0.5$, and $28 \pm 0.5 \mu \mathrm{g} / \mathrm{ml}$, respectively. Of these three extracts, chloroform extract showed a good cytotoxic effect on MCF-7 cells $(22 \pm 1.5$ $\mu \mathrm{g} / \mathrm{ml})$.

Figure 8 represents the apoptotic effect of chloroform extract of $C$. papaya leaves at $10 \mu \mathrm{g} / \mathrm{ml}, 20 \mu \mathrm{g} / \mathrm{ml}$, and $40 \mu \mathrm{g} / \mathrm{ml}$ on MCF-7 cells and analyzed through fluorescence microscopy. With the

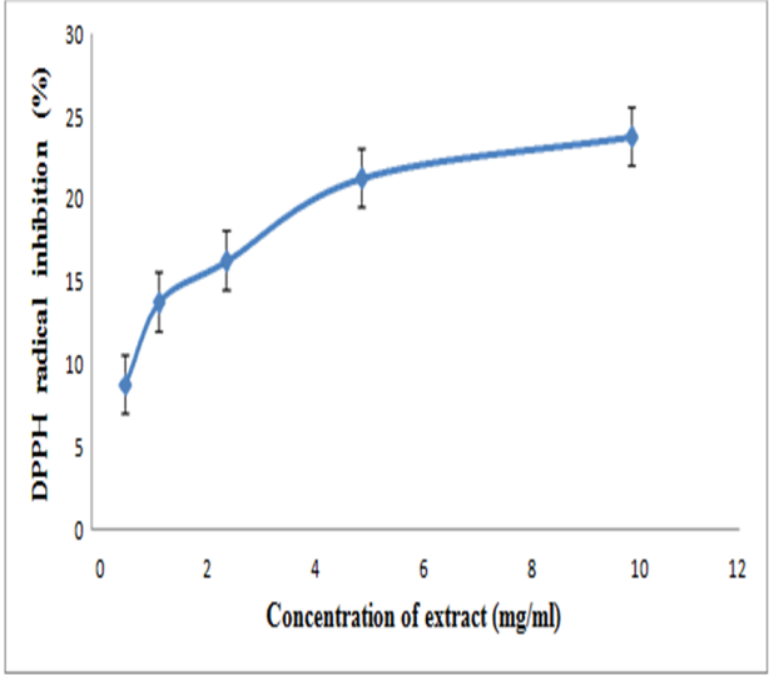

Figure 3 DPPH radical scavenging activity of methanolic extract of C. papaya leaves

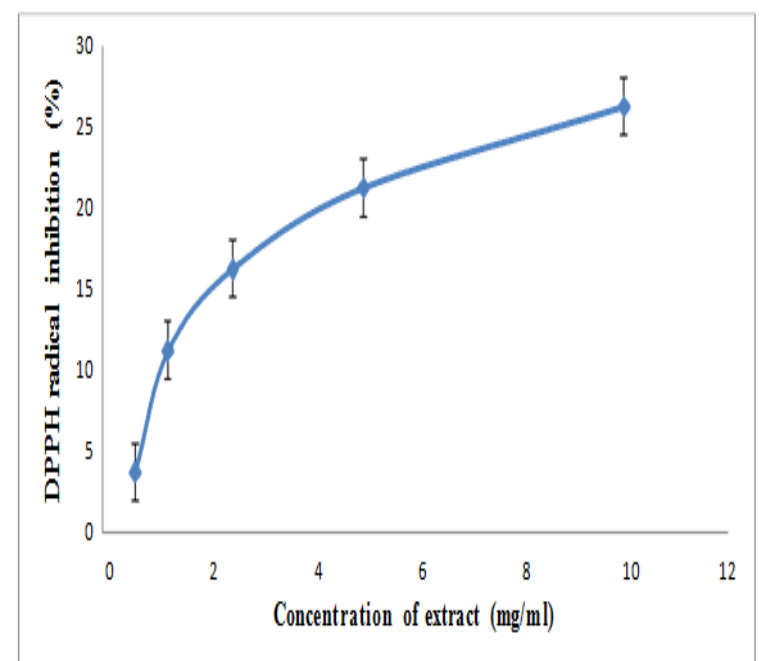

Figure 4 DPPH radical scavenging activity of ethyl acetate extract of C. papaya leaves

increasing concentration of plant extract, a gradual shift from green to red fluorescence was observed in MCF 7 cells, the shift is considered as an index of apoptosis. This is further, supports the apoptotic effect of chloroform extract of C. papaya on MCF-7 cells.

Figure 9 represents the DNA fragmentation assay of chloroform extract of C. papaya leaves on MCF-7 cells. In the image, "M" represents the marker DNA. The concentrations of the sections were $10 \mu \mathrm{g}, 20 \mu \mathrm{g}, 30 \mu \mathrm{g}$, and $100 \mu \mathrm{g}$, respectively. The DNA fragmentation has increased with the increasing concentration of the extract. Thus, results showed that $100 \mu \mathrm{g}$ of chloroform extract of $C$. papaya leaves exhibit more DNA fragments. 


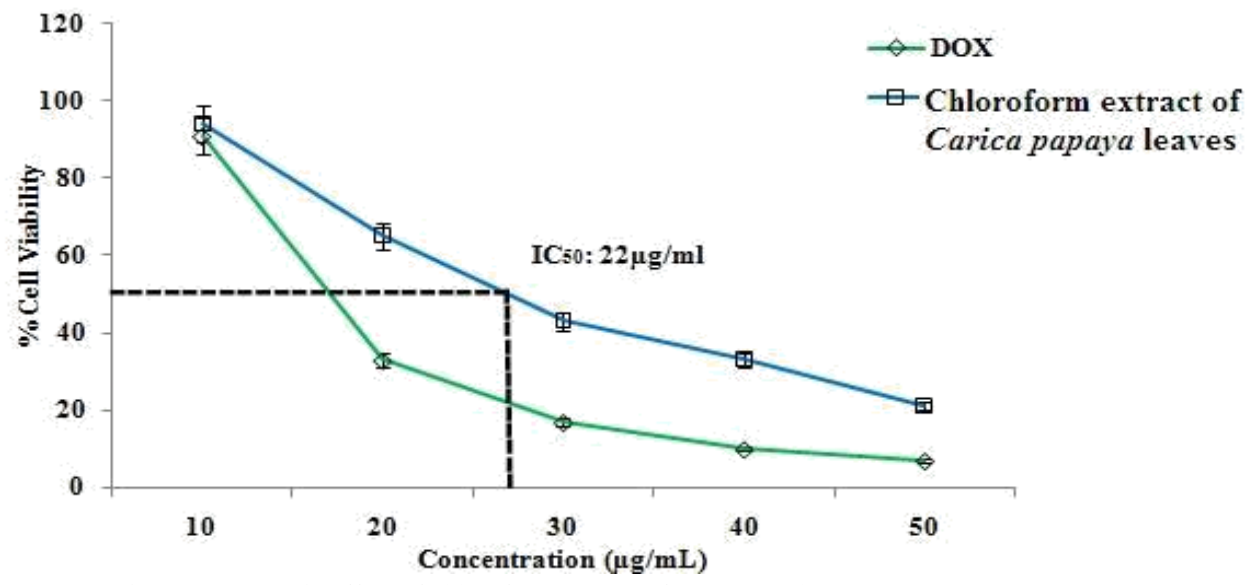

Figure 5 Cytotoxic effect of chloroform extract of C. papaya leaves on MCF-7 (MTT Assay)

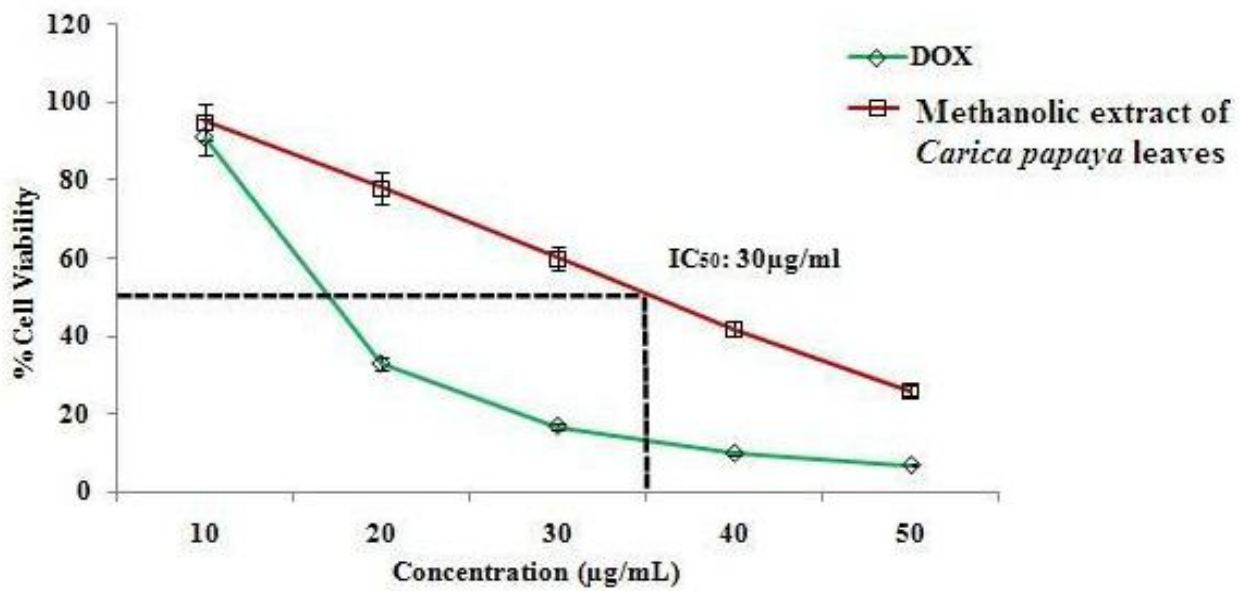

Figure 6 Cytotoxic effect of methanolic extract of C. papaya leaves on MCF-7 (MTT Assay)

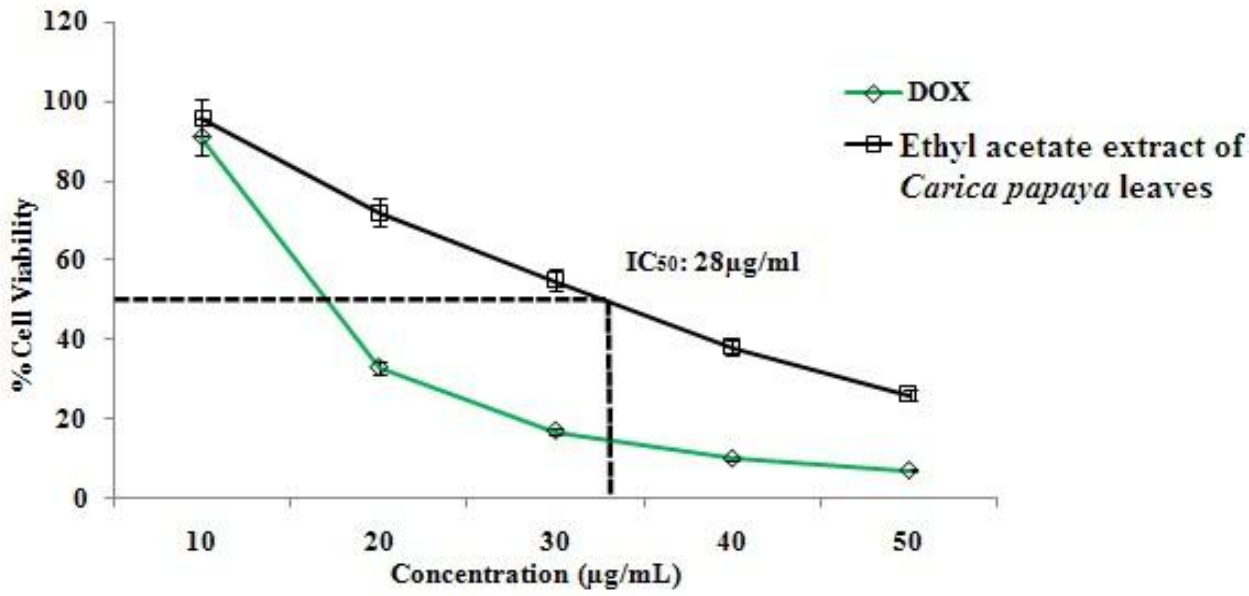

Figure 7 Cytotoxic effect of ethyl acetate extract of $C$. papaya leaves on MCF 7 cells (MTT Assay)

Journal of Experimental Biology and Agricultural Sciences http://www.jebas.org 

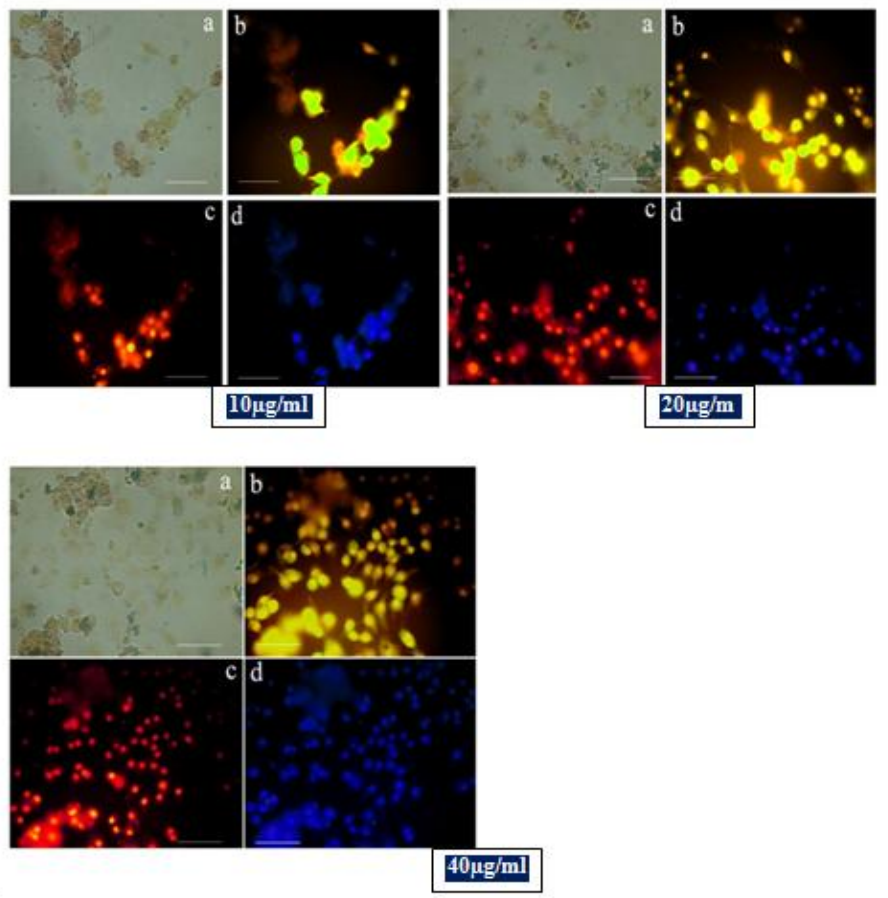

Figure 8 Fluorescence microscopic analysis of chloroform extract of $C$ papaya leaves on MCF-7 ( a - Phase contrast image of MCF-7-cells; $\mathrm{b}$ - Acridine orange and Ethidium bromide image of MCF-7 cells; $\mathrm{c}$ - Propidium Iodide of MCF-7 cells; d- DAPI image of MCF-7 cells)

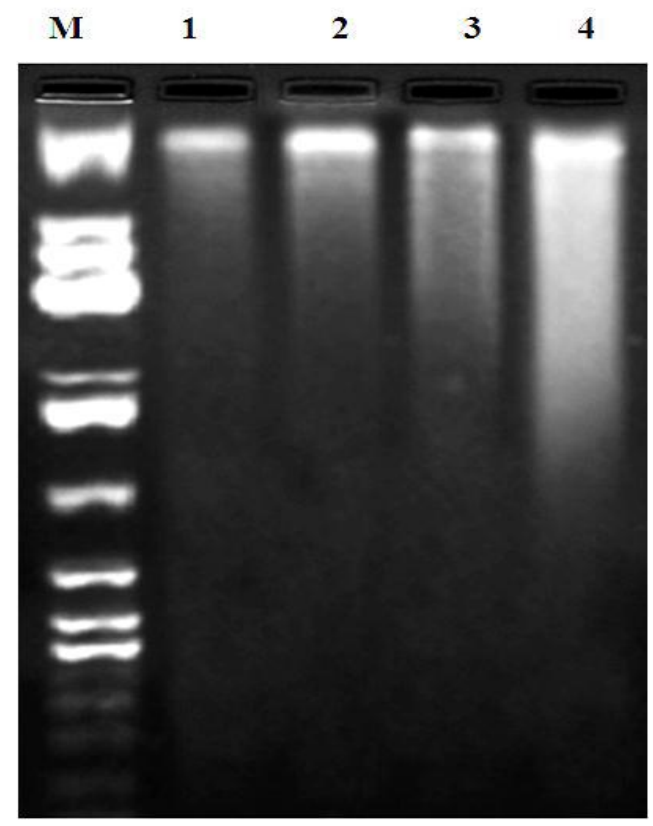

Figure 9 DNA fragmentation analysis of chloroform extract of $C$. papaya leaves on MCF-7 cells (M - Marker DNA; 1 - 10 $\mu \mathrm{g} / \mathrm{ml}$ treated

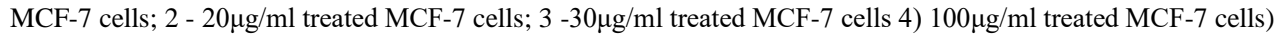

\section{Discussion}

Plants have been used for medical purposes since time immemorial and are the basis of modern medicine. Phytochemicals, secondary metabolites, derived from aerial portions of the plants such as leaves, roots, flowers, seeds, barks, and pulps used to combat several disorders such as asthma, arthritis, cancer, etc. (SahiraBanu \& Cathrine, 2015). In this study, leaves of C. papaya were found to

Journal of Experimental Biology and Agricultural Sciences http://www.jebas.org 
possess several secondary metabolites, and it is in line with Javed et al. (2017). It has also been reported that they activate proteins and signaling pathways against cancer cell progression.

Secondary metabolites have been gaining attention as an alternative therapeutic agent against cancer as they act particularly on cancer cells without disturbing normal cells (Rastogi et al. 2016; Javed et al., 2017). Evidence indicates that the free radicals stimulate oxidative damage to biomolecules which ultimately causes aging, diabetes mellitus, inflammation, atherosclerosis, AIDS, cancer, and numerous degenerative diseases in humans. Flavonoids and free radical scavengers that prevent oxidative cell damage possess good anticancer action (Efferth, 2017). In this study, a similar free radical scavenging effect was observed with C. papaya leaves and this could be due to the presence of the flavonoids in the plant.

Administration of antioxidants for patients with cancer was found to enhance the therapeutic efficacy and longevity of the patient (Singh et al., 2018). Free radical scavenging ability of chloroform extract was found to be more than methanol and ethyl acetate extracts of C. papaya leaves.

Further, the anti-proliferative effect of chloroform extract against MCF 7 was also found to be promising as compared with the other two extracts. Thus, the plant extract possesses antioxidant and cytotoxic effects, researchers suggest that increased free radical scavenging activity, in turn, enhances the cytotoxic effect of plant extract (Suman et al., 2012; Sammar et al., 2019).

Studies on the effect of plant extracts represented major morphological changes, apoptotic characteristics such as shrinkage of the cell, membrane blebbing, and cell density reduced which imply the anticancer activity of the plant extracts (Elumalai et al., 2012; Thangama et al., 2012). The data obtained from the study is in line with previous studies. Similarly, Lu et al. (2014) reported the apoptotic effect of curcumin on MCF-7 cells and observed the characteristic changes of apoptosis. These staining results suggest that the extract triggered apoptosismediated cell death in MCF-7.

The DNA fragments generated as the result of apoptosis were visualized after electrophoretic separation. From the results, a 'ladder' pattern of DNA fragments was observed and this is in line with Harshitha et al. (2019). An increased DNA fragment from the MCF 7 cells treated with chloroform extracts further supports the ant-cancer potential of the leaves extract. Previous studies reported that anti-cancer potential may be attributed to either apoptosis induction or DNA fragmentation or caspase -3 activation of poly (ADP) ribose polymerase cleavage caused by these extracts (Desai et al., 2008)

\section{Conclusion}

In this study, $C$. papaya leaves extract was selected and screened for its anti-proliferative effect against MCF 7 cells. Qualitative analysis of different extracts revealed the presence of several secondary metabolites which were proven anti-cancer phytoconstituents. From the data obtained, it may be concluded that the $C$. papaya could be used as an alternate anticancer agent and as a good antioxidant.

\section{Conflict of Interest}

Nil

\section{References}

Alam S, Katiyar D, Goel R, Vats A, Mittal A (2013) Role of herbals in cancer management. The Journal of Phytopharmacology $2(6): 46-51$

Chang CC, Yang MH, Wen HM, Chern JC (2002) Estimation of total flavonoid content in propolis by two complementary colorimetric methods. Journal of Food and Drug Analysis 10: 178182 .

Desai AG, Qazi GN, Ganju RK (2008) Medicinal plants and cancer chemoprevention. Current Drug Metabolism 9:581-91.

Efferth T (2017) From ancient herb to versatile, modern drug: Artemisia annual andartemisinin for cancer therapy. Seminars in Cancer Biology 46: 65-83.

Elumalai P, Gunadharini DN, Senthilkumar K, Banudevi S, Arunkumar R, Benson CS, Sharmila G, Arunakaran J (2012) Induction of apoptosis in human breast cancer cells by nimbolide through extrinsic and intrinsic pathway. Toxicology Letters 215(2) $131-142$

Engin U, Ceyda A, Ferda A, Eliflkitimur, Yilmaz Y (2011) A Glance at the methods for detection of apoptosis qualitatively and quantitatively. Turkish Journal of Biochemistry 36(3): 261-269.

Fadi MA, Ferguson T (2020) Breast Cancer. A service of the National Library of Medicine, National Institutes of Health.

Farr KJ, Gallaway PJ, Hongu N (2017) Breast Cancer Prevention. Exercise and Healthy Diet. Available at https://extension.arizona.edu/sites/extension.arizona.edu/files/pubs/ az1724-2017.pdf access on 29th April 2021.

Feng Y, Spezia M, Huang S, Yuan C, Zeng Z, Zhang L, Ren G (2018) Breast cancer development and progression: Risk factors, cancer stem cells, signaling pathways, genomics, and molecular pathogenesis. Genes and Diseases 5(2): 77-106. 
Harbone JB (1998) Phytochemical Methods. 3rd ed. Chapman and Hill, London.

Harshitha B, Subhada B, Mustafa M, Solanki H, Safiya NAM, Tiwari RVC (2019) DNA laddering to evaluate cytogenetic damage in patients with periodontitis. Journal of International Society of Preventive and Community Dentistry 9: 486-491.

Indumathi CG, Nithyavani DS, Gayathri PK (2014). Estimation of terpenoid content and its antimicrobial property in Enicostemmalitorrale. International Journal of ChemTech Research 6 (9): 4264 - 4267.

Javed I, Banzeer AA, Tariq M, Sobia K, Barkat A, Sayed AS, Ali TK(2017). Plant-derived anticancer agents: A green anticancer approach. Asian Pacific Journal of Tropical Biomedicine 7: 11291150 .

Joseph A, Sridharan S, Palanisamy S, Ramalingam S, Saravanan R (2020) Identification of anticancer compounds from Linumu sitatissimum seed extract and their effect on HeLa cells. Pharmacognosy Magazine16:221-6.

Kiruthika D, Renuka S, Sheik Abdulla, Shahul Hameed, Sivakumar Ramalingam (2020) Evaluation of Anticancer Potential of Vitus vinifera Seed Against Breast Cancer Cells - MDA-MB231. Pharmacognosy Journal 12(5): 1064-1071

Kokate CK, Purohit AP, Gokhale SB (2001) Carbohydrate and derived Products, drugs containing glycosides, drugs containing tannins, lipids and protein alkaloids. Text book of Pharmacognosy 7: $133-523$

Levitsky DO, Dembitsky VM (2015) Anti-breast Cancer Agents Derived from Plants. Natural Products and Bioprospecting 5: 1-16.

Lu M, Lawrence DA, Marsters S, Acosta-Alvear D, Kimmig P, Mendez AS, Paton AM, Paton JC, Walter P, Ashkenazi A (2014) Opposing unfolded-protein-response signals converge on deathreceptor activation to control apoptosis. Science 345: 98.

McDonald S, Prenzler PD, Antolovich M, Robards K (2001) Phenolic content and antioxidant activity of olive extracts. Food Chemistry 73: 73-84.

Mensor LL, Menezes FS, Leitao GG, Reis AS, Santos TCD, Coube CS (2001) Screening of Brazilian plant extracts for antioxidant activity by the use of DPPH free radical method. Phytotherapy Research 15 (2): 127-130.

Mustikasari K, Ariyani D (2010) Phytochemical screening of Kalangkala (Litsea angulata) seed methanol extract. Sains dan Terap Kim 4(2):131-6.
Padmapriya P, Maneemegalai S (2014) Qualitative and quantitative analysis of the phytochemical constituents of Mollugo cerviana (L). International journal of pharmaceutics and drug analysis 2(9): 695-699.

Thangama R, Gunasekaran P, Kaveri K, Sridevic G, Sundarraja S, Paulpandia M, Kannan S (2012) Novel disintegrin protein from Najanaja venom induces cytotoxicity and apoptosis in human cancer cell lines in vitro. Process Biochemistry 47:1243-1249.

Rastogi S, Srivastava N, Virmani T, Singh C, Gupta J (2016) A review on naturally derived compounds for potential anticancer activity. Indian Journal of Drugs 4(3): 75-86.

Richard TS, Kamdje AHN, Mukhtar F (2015) Medicinal Plants in Breast Cancer Therapy. Journal of Diseases and Medicinal Plants 1(1):19-23.

SahiraBanu K, Cathrine L (2015) General Techniques Involved in Phytochemical Analysis. International Journal of Advanced Research in Chemical Science 2(4):25-32.

Sammar M, Abu-Farich B, Rayan I, Falah M, Rayan A (2019) Correlation between cytotoxicity in cancer cells and free radicalscavenging activity: In vitro evaluation of 57 medicinal and edible plant extracts. Oncology Letters 18(6):6563-6571. doi: 10.3892/ol.2019.11054.

Saravanan R, Pemaiah B, Narayanan M, Ramalingam S (2017) Invitro cytotoxic and gas chromatography mass spectrometry studies on Orthosiphon stamineus Benth. Leaf asainst MCF-7 cell lines. Asian Journal of Pharmaceutical and Clinical Research 10(3): 1-7.

Saurabh P, Peter JCP, Nicholas S, Amitha KH (2016) Antiinflammatory and immunomodulatory properties of Carica papaya. Journal of Immunotoxicology 13 (4): 590-602.

Schanderl SH (1970) In: Methods in Food Analysis. Academic Press, New York, London, Pp.709.

Shareef M, Ashraf MA, Sarfraz M (2016) Natural cures for breast cancer treatment. Saudi Pharmaceutical Journal 24(3): 233-240.

Silas I, Bolarin JA, Nigeria FI (2019) Qualitative Analysis of Secondary Metabolites in Cetaurea senegalensis Plant. International Journal of Innovative Research and development 8 (6): 176-180.

Singh K, Bhori M, Kasu YA, Bhat G, Marar T (2018) Antioxidants as precision weapons in war against cancer chemotherapy induced toxicity - Exploring the armory of obscurity. Saudi Pharmaceutical Journal 26(2):177-190. 
Suman S, Pandey A, Chandna S (2012) An improved non- Yahyea BL, Romen ML, Pranab BM (2019) Herbal Remedies for enzymatic "DNA ladder assay" for more sensitive and early Breast Cancer Prevention and Treatment. IntechOpen detection of apoptosis. Cytotechnology 64(1): 9-14. 10.5772/intechopen.89669. 